\title{
THE EFFECT OF BILINGUALISM ON INTELLIGENCE
}

\author{
BY D. J. SAER. \\ I. Introduction (p. 25). \\ II. The Problem (pp. 25-27). \\ III. Tests on School Children. \\ (a) Stanford Binct (pp. 27-28). \\ (b) Dextralit!y (pp. 28-29). \\ (c) Rhythm (pp. 29-30). \\ (d) Tocabulary (p. 30). \\ (e) Composition (pp. 30-32). \\ IV. Tests on University Students. \\ (a) Tests of 1921 (pp. 32-34). \\ (b) Tests of 1922 (pp. 34-37). \\ V. Conclusions (p. 38).
}

\section{Introduction.}

THE use of the native language in a subject-state tends to weaken in favour of the language of the governing state: yet a people will not readily abandon their language and adopt another. Even where a new language has been generally adopted by a community and the native language has gone out of use, certain forms of the old language will remain as permanent characteristics of the new.

The symbols first learnt for expressive use by the human mind are very persistent, and man is incapable of entirely changing them.

Under British rule there are many peoples who speak other tongues, and, consciously or unconsciously, the English language is coming gradually to prevail in the subject-states of Britain, the natives during the process passing through various stages of bilingualism. In the large towns of England itself there are colonies of people whose mother tongue is alien, and in Wales we have whole counties where the large majority of the people speak Welsh as their mother tongue.

\section{The Problem.}

During the last four years I have attempted a somewhat intensive investigation of the effect of bilingualism on the intelligence of people 


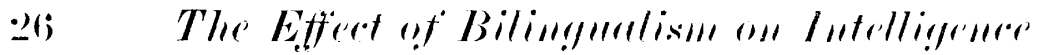

in a subject-state, in districts where the native languatere is anderally spoken, and also in districts whem hoth the andire langulage and that of the groverning state are lased ireerly.

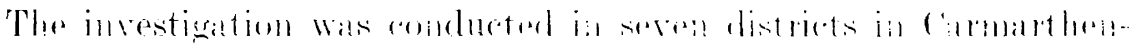

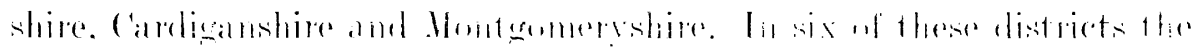

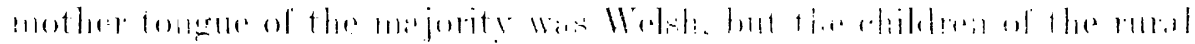

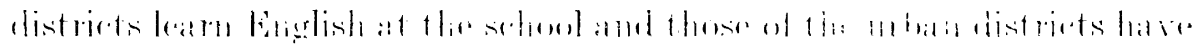

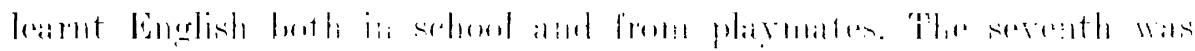

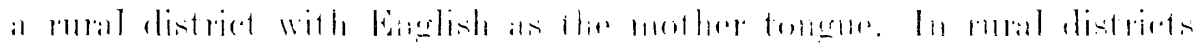

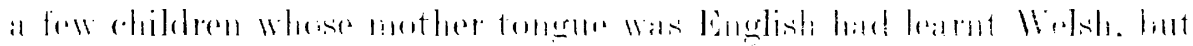

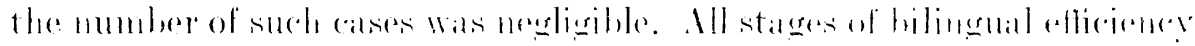

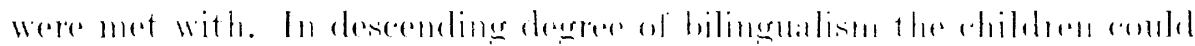
be grarted thus:

\begin{tabular}{|c|c|c|c|c|}
\hline $\begin{array}{l}\text { Hoibure } \\
\text { lintubutere }\end{array}$ & 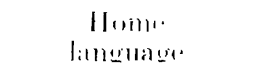 & 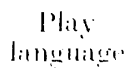 & 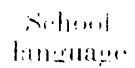 & $\begin{array}{l}\text { 'limbels } \\
\text { languatse. }\end{array}$ \\
\hline I. $W_{i}|\leqslant|_{1}$ & $\mathrm{H}_{1} \cdot 1 \leqslant \mathrm{~h}$ & $1 W_{1} \cdot N b$ & Findistis & $\left\|W_{1}\right\|_{1}$ \\
\hline$\therefore \quad$ Mrelsh & 11 . Wh & English & linglish & $\|$ IIN \\
\hline is. Winh & $\begin{array}{l}\text { Euglish by childs } \\
\text { choice after first } \\
3 \text { or }+ \text { rears }\end{array}$ & English & Enluli: h & Milsh or Fingli \\
\hline 4. $\quad$ lin: & Englisili & $11+1:$ & & linglish \\
\hline$\therefore$ Enslish & English & Endish & Fnulint & English \\
\hline
\end{tabular}

Five of the districts were rumal where the sor lal conditions and habits of the people were very nearly alike. The other 1 wo districts were urban and industrial. With rery few exceptions the whold child pepulation from 7 to 12. gears of age was tested. The headmasters of the schools gave me their ready help. They placed a quiet rom at my disposall. and supplied reliable information as to the social position. home language and the age of each child. Nearly 1 fou children were examined individually, and as the examnations were all comducted personally, the standard of estimation was uniform throughout.

Every child was tested hy means of his mother tongue, as I found. hy an experiment on ltir boys who were retested alter an interval of more than a rear, that eren when Welsh speaking berse are able to speak English fluently aind prefer it to Welsh, since lloy use it in their play, their mother tongue is the best omal mentimn lag which we an gain a just estimate of their mental capacity. In rumal Welsh speaking districts, when the children were addressed an Melsin. their shyness disappeared, they immediately hecame interesterl. natmal in attitude and responsive, their best effort heing thus readily secoment.

In the years 1921 and $192 \cdot 2$ I set an Intellignion test to more than bov older people, students at the Linersity. College of Wales. Aberystwyth. 
The tests were devised to estimate the relative mental capacity of these persons for purposes of comparison with their academic attainments. On reviewing the results of these tests, after securing information as to the language first spoken by each student and his home address, further evidence was obtained for considering the effect of bilingualism on intelligence and the persistence of that effect.

\section{Tests ON SCHOOL ('HILDREN.}

The tests on school children are explained under five headings: (a) the Stanford Binet scale, (b) Dextrality, (c) Rhythm, (d) Vocahulary, (e) C'omposition. A fuller account of the first four is given in the Journal. of Experimental Pedagogy, vol. vi, 1922, nos. 4 and 5, except that the figures given in the present article include 53 cases of urban children who were examined subsequently.

\section{(a) The Stanford Binet-Simon scale.}

All the children examined were tested by the Stanford revision of the Binet scale, to which were added those tests in Binet's 1911 scale as well as those in Burt's English version of the Binet which were omitted from the Stanford scale. With the record thus secured, after testing the children individually, it was possible to calculate the mental age of each child according to the three scales. This device proved useful as a check upon errors of calculation in individual cases, and also as a means of observing the consistency of the general tendency of the conclusions.

The test questions were carefully translated into a style of Welsh easily comprehended by Welsh-speaking children, and each child was tested by means of his mother tongue.

In one district children over 11 years 5 months were not tested, but as the Binet scale was found not to give consistent results with children over 12 when they were re-examined after an interval of a year, the record of such children can be ignored for the moment.

The following table of frequencies will represent the difference between monoglot and bilingual children in rural and in urban districts:

Frequencies of I.Q.'s with children 7 to 11 years old.

\begin{tabular}{|c|c|c|c|c|c|c|c|c|c|c|}
\hline I.Q.'s & 50 & 60 & 70 & 80 & 90 & 100 & 110 & $1: 0$ & 130 & 1407 \\
\hline Rural monoglots & - & - & 8 & 23 & 33 & 39 & 3 & 1 & - & - \\
\hline Rural bilinguists & 9 & 13 & 58 & 110 & 93 & 23 & 4 & - & - & - \\
\hline Urban monoglots & - & - & 3 & 21 & 58 & 36 & 20 & 7 & 3 & 2 \\
\hline Urban bilinguists & - & - & 7 & 32 & $9: 2$ & 86 & $3 \tilde{5}$ & 4 & 1 & 4 \\
\hline
\end{tabular}




\section{-x The Effect of Bilingualisme and Intrlligener}

The next table gives the median mental age of the same children at each year of physical a ger 7 to 11 years.

\begin{tabular}{|c|c|c|c|c|c|c|}
\hline ('lisss & Physinal alu (y)s! & $i$ & $\therefore$ & $!$ & 111 & 11 \\
\hline Rural monogrots & Mental atere trest & 7 & $7 \cdot$ & $x \cdot 3$ & $9+1$ & 111.2 \\
\hline Rural Ijilinguists &.. & iin & $7 \cdot 1$ & $7 \cdot S$ & 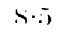 & 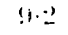 \\
\hline Urhan monoglots & .. & $7 \cdot 4$ & $7 \cdot 9$ & 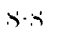 & $11 . \pi$ & $111 . .7$ \\
\hline Urban bilinguists & ,. & $i \cdot 4$ & $x+11$ & $! \cdot 11$ & : 1.t. & $10 \%$ \\
\hline
\end{tabular}

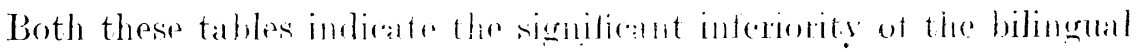
children in dural districts when tested he the stanford scalle, the latter table suggesting that this inforionity becomes onsistently greater in degree with each year from 7 to 11 years of age.

The percentile graph for these sos children gives farly smonth arves for each of the four classes named, with the lollowing features. Ther curves for urban monoglotis and urban bilinguists are bery nealy antcurrent, and cross each other five times, while the curve for rumal momeglot children is superior to that for rumal hilimgual children al riath percentile. At the median of either curve a herizental line meets the other curve at a distance of 30 percentiles.

\section{(b) Inextrality.}

As it was noticed at an early stage of the investigation that bilingual children had not as unerring a sense of dextrality as the monoglots, the difference in this respect was thereafter olserved more rosely. Note was made of a consistent reversal of sides throughout a test of six responses, and of undue hesitation or apparent confusion hefore griving the correct response. Correct responses to such a test are generally expected in normal children of di yars old. It was therefore expected that children of $x$ years and upwards would pass this test with eatse.

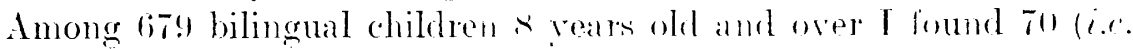
$1(1.3$ per cent.) who responded consistently with a wersial of right and left and 103 (or $155 \cdot 1$ per cent.) who were confused or hesitated unduly. Total 173 or $25 \cdot 4$ per cent.

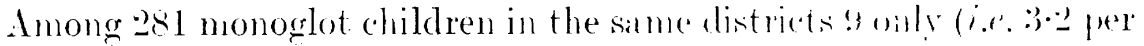
cent.) showed reversal, and 1.j (i.e.j.3 per cent.) shownil undue hesitation. Total 24 or $8 \cdot 5$ per cent.

In the urban districts, considered separately, the percentages for: bilingual children were $i \cdot 3$ s per cent. reversals. and $17 \cdot 6$ per cent. hesitation. Total 25 per cent.

With urban monoglot children the reversals were -2.30 per cent.. and hesitations 8.33 per ceit. Total $10 \cdot 7$ per cent. 
These figures show a marked superiority in the monoglots over the bilinguists in their sense of dextrality in both urban and rural districts.

Dr Mott is reported" as stating that "Symbolic language is a social heritage in which auditory and visual symbols have been used, especially by civilized races, to express judgments and feelings. The fact that in all right-handed people it is represented in the left hemisphere shows that it has developed with the specialization of use of the right hand."

In every case represented above the bilingual children had begun to learn a second language at an age when they had not acquired an adequate power of expression in their mother tongue, and the linguistic symbols in writing and reading had been presented to them in the second language. Some confusion must hare arisen under these conditions, and the greater the affective value of the mother tongue the greater would be the confusion in the rapidly developing mind.

\section{(c) Rhythm.}

A graduated series of six rhythms was given to 258 unselected boys in an urban school. Each rhythm was tapped on a table with a pencil out of the sight of the boys, who were taken individually in a quiet room. They were then required to repeat the rhythm by tapping it on the table. After the six exercises had been completed, they were again given one by one, but this time the stimulus and the response were by singing the rhythm to 'laa.' Marks with a maximum of 4 for each rhythm were allotted for correctness in 'attack,' length, and consistency of rhythm.

\section{Mcdian. Markis obtained in the Rhythm tests.}

\begin{tabular}{|c|c|c|c|c|c|c|}
\hline \multicolumn{7}{|c|}{ (Maximum $2 \pm$ marks.) } \\
\hline \multicolumn{7}{|c|}{ Monoglots } \\
\hline Age (yrs.) & 7 & 8 & 9 & 10 & 11 & 12 \\
\hline 'Tapping & $8 \cdot 8$ & 11 & 14 & $14 \cdot 5$ & 17 & $17 \cdot 5$ \\
\hline Singing to 'laa' & $14 \cdot 8$ & 16 & 17 & 18 & 18 & $18 \cdot 5$ \\
\hline \multicolumn{7}{|c|}{ Bilinguists } \\
\hline 'Tapping & 10 & 10 & $14 \cdot 6$ & $14 \cdot 8$ & 14 & $14 \cdot 8$ \\
\hline Singing to laa' & $13 \cdot 4$ & $15 \cdot 5$ & 16 & $16 \cdot 8$ & $16 \cdot 8$ & $16 \cdot 8$ \\
\hline
\end{tabular}

In the tapping exercise the monoglots were superior at 8,11 and 12 years of age, but the bilinguists were superior at 7, 9 and 10 years. Yet, when the rhythms were sung to 'laa,' the monoglots were superior at each year of age.

The gain obtained on repeating the rhythms by singing was 3.45 marks per child on the average in the case of the monoglots, while the

1 Brit. Med. J., Dec. 11, 1915. 


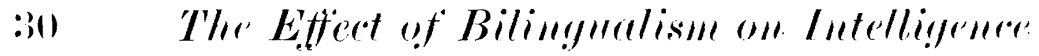

bilingual boys gained an average of $2 \cdot 84$ markis on the repetition of rhythms by using the organs of speech.

\section{(d) Vicabulary.}

In order to secure a comparative estimate of the rhildren's range of rocabulary in English and in Welsh, I made use of Anwyl's Welsh dictionary and drew up four lists of 100 words each, selecting erery word as it came at the end of even steps taken four times through the dictionary. The too words thus found were then arranged in the order of their apparent difficulty to children, and every fourth word in this list was selected to make up the fimal list of $1(11)$ words which was used for testing. The number of words from this list comprehended by a chiled was taken as indicating the percentage of the Melsh vocabulary that had heen acepuired by him. The first list of 1011 words wiven in the Stanford scale was used for estimating the child's range of Enelish vocabulary.

It was found that at 10 yeals of aloe in rural distriets there wats a sharp rise in the range of the bilingual children is vecabulary in lonth English and Welsh, and that the mean ration of Walsh vocabulary to English rocabulary langed from $3 \cdot 17$ at 7 yads to $-2 \cdot 4$ at 12 years of age. In the case of the monogrot English-spealinge children in rural districts the most comsiderable rise in vocabulary appeared at $R$ gears and the next at ! years of are.

In the urban distriets the sharjest rise in the ranger of the English

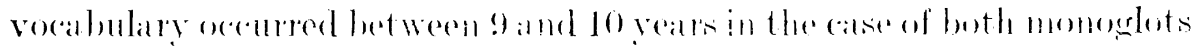

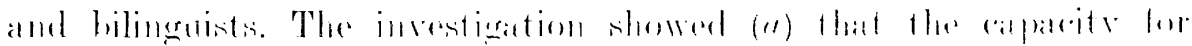

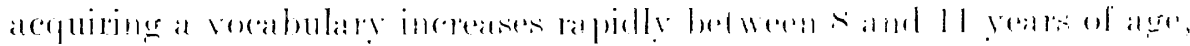

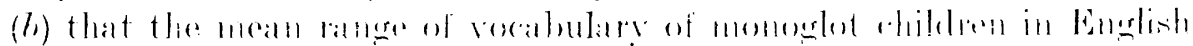
wats ligher than that of bilingual children risher in Engrlish or Welsh.

\section{(a) Compusilion.}

In his article on bilingualism and nental derolojment ${ }^{1}$ frank simith shows that four sroups of scholats investierated independently and umber observation for two rears, developerd at a different rate in their prome of free composition (in Enerlish) alecording as they wore momoghot on bilingual. The superionity in rach calse, significant in amount, is with the monoglot. A sujerionity of the monoglots was also shown in the

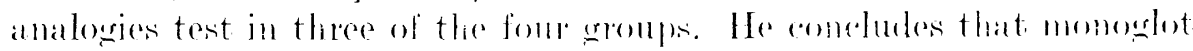
children between the ages of $x$ and 11 make better progress than bilingral children in their power of expression, their choice of rowahulary and

1 This Journal, xin, 278 
their accuracy of thought; and that so far from bilingualism being an "intellectual advantage" it seems to be exactly the reverse, at least under the present organisation of schools in Wales.

To test their power of expression in Welsh and in English I asked children of 9 years and upwards in the various districts examined to write in Welsh a true account of the dream they had last experienced, to write it exactly as it occurred and add nothing that was not in the dream. I impressed upon them that I wanted to find out whether they could give a true and exact account, and that the dreams would be kept private. They were asked to write with a pencil in order to aid their freedom of rapid expression and were told not to bother about the spelling or the neatness of the writing. After a child had completed that exercise, he was asked to write-this time in English-about the thing he liked best of all. He was again allowed to write with the same freedom from spelling and penmanship inhibitions.

Over 400 of these scripts were received. Monoglot English-speaking children, of course, wrote both exercises in English. In many cases the spelling of Welsh was delightful in its independence of the rules of orthography, but very few exercises were found so original in the spelling as to be difficult to decipher. English composition had been taught at the schools but there was no evidence that much serious written composition in Welsh had been attempted. After reading the papers through several times the following features became evident:

(a) In the Welsh accounts of the dreams the sentences are generally well-connected and are expressed lucidly in rather good conversational idiom, with completeness of expression and continuity of thought, while the English exercises by the same children are in short sentences disconnected in form and thought, and frequently mixed in the tenses.

(b) The choice of subject to represent the thing they liked best indicated a difficulty in thinking outside the groove of thought into which the school lessons in English had led them. Nearly 50 per cent. chose such animals as the cow or horse, stating that it was a four-footed animal with two eyes, one tail, etc.; 45 per cent. wrote about articles of food; the home, the mother, the school, or money in phrases that were bookish and apparently not well comprehended. About 5 per cent. only chose to write about trains, ships, motor bicycles, aeroplanes.

(c) Evidence of reasoning in the exercises was very much more frequently met with in the Welsh exercises than in the English exercises of the bilingual children.

(d) While the rudiments of an individual style of expression were 


\section{:30- The Etfect of Bilingualism on Intrlligenere}

evident in the Welsh sentences, the English phrases, were palpably snatches of school lessons and indifferently memorised verbal expressions that had not as yet been comprehended by the child or adopted by him as his very own, for the disconnected expressions in English can hardly be said to be fully appreciated by him. Not until appreciation has become a significant part of the child's attitude towards any phrase can its adoption by him be looked for with any contidence.

\section{Tests on University átutuents.}

(a) Tests of 1921 .

At the beginning of the C'hristmas torm 1921, the candidates for entrance scholarships at the University ('ollege of Wales, Aberystwrth, the students in the normal department and the ex-soldier special training class worked a 'General Paper' which I drew up to test their intelligence. The normal department consisted of a number of wracluates in their fourth year, as well as students in their third, second or first academic rear. They formed a group of people who would generally be classed as "superior adults' who hailed from England and from all parts of Wales.

An effort was made to secure conditions as similar as possible under which the test was worked by each group. The 170 students in the normal department who worked the paper formed a homogeneous wroup upon whose performance I was mabled to "weight" the marks, the maximum marks allocated to each question being in proportion to the reciprocals of the logarithms of the number of correct answers criven to the question by this homogrenerous group.

The validity of the paper as a test of intelligence,- that it tested a mental feature which did not appear to increase by acarlemic training, and would be as evident in a student on his entrance to college as it. would be when he completed his course--is shown ly the relative standing of the various groups tested, which were as follows:

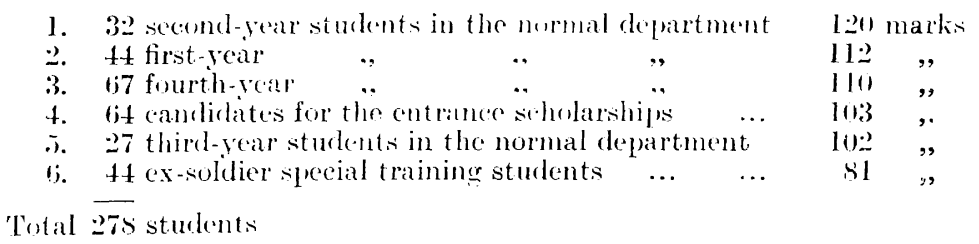

The class standing was found by calculating the percentage of correct answers made by each group in each of the nine sections of the paper, arranging these percentages in order of value, noting the number of times a group stood first, second, third, etc., and then allocating relative 
marks for the positions thus secured. The maximum mark, where a group stood first in all sections of the paper, was 126 , and the minimum mark 81 , where a group stood last in all sections.

On this basis we find that first- and second-year students worked the test as successfully as students in their third and fourth year.

The instructions given, before the test was commenced, included the following: "There are 60 questions, many of them quite easy, and you are not likely to find any question very difficult if you think calmly about it. Sufficient time to complete the paper will be allowed those who work at a fairly rapid rate. Work rapidly and carefully. Do not guess, and do your best to complete the test in the time allowed which will not be over an hour, and it may be less."

The paper was divided into nine sections:

Section 1 consisted of statements which were paraphrases of ten proverbs followed by a list of the proverbs themselves. Students were asked to write after each proverb the number of the statement that they considered best interpreted it.

Section 2 contained ten incomplete analogies which were to be completed by adding an appropriate word to each.

Section 3 contained eight reasoning tests involving simple numbers, e.g.

"A man is 15 years older than his brother. In the year 1910 he was twice as old as his brother. How old was the man in 19:0."

"A block of wood 4 inches long and 3 inches wide on the top face and 2 inches thick, is painted on its four sides but not on the top and bottom faces. It is then sawn into one inch cubes. (a) How many of the cubes will be found painted on two sides? (b) How many will be painted on one side? (c) How many will not be painted on any side?

Section 4 asked for words having exactly the contrary meaning to 20 given words.

Section 5 gave ten statements, e.g., "We can hardly contend that it is not conducive to fatigue to climb a high mountain." The last word of any statement that was correct was to be crossed out, and the first word of any absurd or false statement had to be underlined.

Section 6 provided exercises in following directions, e.g., "If Scott wrote 'Henry Esmond' cross out the word No, unless you think that Dickens wrote 'Oliver Twist' in which case you should draw a line under that word."

Section 7 asked that the clearest and most pertinent feature in a given well-known book should be described in one word. Four books were then named.

J. of Psych. xir. 1 


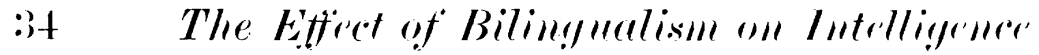

section $x$. In the following questions underline that word in the second group which denotes what is referred to in the first group:

"Upright, crafty, indolent.".-... Life, health, character, religion," otc.

Section 9 was a 'Completion test,' twenty-one words being omitted from an extract from a fable; the students were asked to write the appropriate word in the spaces indicated.

Two students completed the paper in 17 minutes. The arerage time taken was 3ij minutes. The median mark obtained was t33 out of a maximum of 6is.) matkis. the standard deviation beinge is marks.

After excluding 14 sturlents in the ex-soldier special training class. which stood last in the list given above, and also 37 students from England. we have 197 students who ame up from llates. Of these 102 had learnt Welsh as their mother tomene and the mother tomgure of the 95 other students from IVales was Englist.

The median mark of the Welsh-speaking students, who, of course. were bilinguists, was 117 , while the median marli of the students whose mother tongue was Engrish anominted to hiti.

The marks of these two sroups at atrh lo percentile were as follows:

\begin{tabular}{|c|c|c|c|c|c|c|c|c|c|c|c|}
\hline & $L$ & 101 & 11 & (1) & 41 & in & ;i & 11 & ו1) & 90 & \\
\hline & & 31 & $3+4$ & 375 & $3 !$ & +17 & +30 & & $4 \times 1$ & 11 & 57 \\
\hline inglish monogrots & $2: 2$ & 337 & $39 ! 3$ & $4: \cdot 2$ & $43 . \overline{5}$ & $466 i$ & thij & 499 & ill & .332 & Itis \\
\hline
\end{tabular}

A graph constructed from the above figures shows that the standard attained by 5n per cent. of the bilingual students from Wales in this test is attained by is per cent. of the monoglots of the same country.

\section{(b) Tests of la).}

At the beginning of the present session I drew up another Intelligence test for the candidates taking the Entrance scholarship examination at the same college, the paper being also taken hy students in the normal department as on the previous occasion.

The conditions of the two tests (that of 1921 and 192-2) differed as regards the time factor. In the 1921 test, emphasis was laid on speed, while in the 1922 test that was onitted, are being now taken to aroid hurrying.

In the latter paper (a) ureater prominence was given to the 'completion test: two selections were given for completion by writing appropriate words in spaces indicated. One was taken from (On sitor!y Telling by Richard Steele. and the other-aselected hy Professor Rose - was from one of Plato's dialogues. 
(b) The test was more difficult and a longer time was allowed for working it.

(c) An attempt was made to estimate the following factors.-Perception of the concrete and verbal perception, ability to control, sustain and concentrate attention; ability to hold in mind the conditions of a problem; ingenuity and practical judgment; steadiness of purpose; ability to use imagery; generalization, reasoning, delayed memory, orientation, and also exactness and rate of mental functioning.

(d) An option was given to answer questions either in Welsh or English where there might be a difficulty in clear expression of the response.--Advantage of this option was taken by several students, and difficulties of expression on account of bilingualism were thus to some extent reduced.

In spite of these differences the correlation between the marks obtained by 70 students who took the 1921 test and also that for 1922 , worked out by the Bravais-Pearson Product Moment formula was

$$
r=.524 \pm \cdot 09 \text {. }
$$

The 1922 test was worked by 333 students. The shortest time taken by any student to complete was 40 minutes; the longest time taken was 106 minutes.

The mean time taken by the Upper Quartile (83 students) was 72 minutes

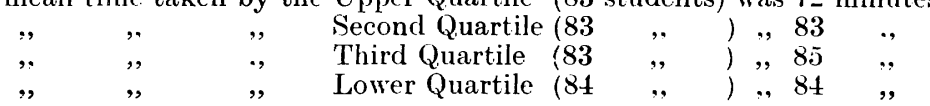

The maximum marks for each question were 'weighted' on the same plan as that for the previous test. The maximum mark for the whole paper amounted to 250 . The median mark for all students was 107 , and the standard deviation was 17 marks.

By disregarding students coming from places outside Wales, who constituted a 'Selected' class, we have 291 unselected students left for comparison who have come up from all parts of Wales. This provides a sufficient number of cases for dividing up into four groups similar in nature to the groups under which the children were considered in Section III.

$8 \cdot 2$ students were bilinguists from rural districts in Wales. Their mother tongue was Welsh.

45 were monoglots with English as their mother tongue. These students again came from rural districts in Wales.

$7 \cdot 2$ were bilinguists having Welsh as their mother tongue from urban and industrial districts in Wales, 


\section{:36 The Etfiect of Bilingualism on Intelligennet}

(92) were monoglot English-speaking students from urban and industrial districts in Wales.

The following table of frequencies shows how these four groups stand. The frequencies are worked out in steps of 17 marks (the standard deviation) counting on either side from the median mark--107.

\begin{tabular}{|c|c|c|c|c|c|c|c|c|c|c|}
\hline Marks & 39 & it & 73 & 90 & 107 & 1.4 & $1+1$ & 1.5 & 17.5 & $\begin{array}{l}\text { No of } \\
\text { rasces }\end{array}$ \\
\hline Rural Welsh bilinguists & 2 & 6 & $1 i$ & $\because 2$ & $\because 1$ & 14 & 1 & 11 & 0 & 52 \\
\hline Rural English monoglots & (1) & 1 & 9 & ! & $1 \stackrel{2}{2}$ & 18 & $\because$ & 11 & 0 & $4 . \overline{1}$ \\
\hline Urban Welsh bilinguists & 11 & $\stackrel{2}{2}$ & 12 & 14 & 21 & 1.5 & 4 & t & 11 & $7: 2$ \\
\hline Urban English monoglots & 11 & $\because$ & $1: 2$ & $\because 1$ & $\therefore 5$ & 19 & $\therefore$ & 1 & 1 & 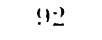 \\
\hline & $\because$ & 11 & $4 !$ & $131 ;$ & 79 & (ii) & 15 & $s$ & 1 & 291 \\
\hline
\end{tabular}

The curves representing these numbers in a graph show a clear superiority of the monoglot over the bilingual student coming from rural districts in Wales, while the difference between these linguistic aroups from urban and industrial districts is inconsiderable.

The marks (maximum 250 ) at each percentile representing the same groups are given in the following table:

\begin{tabular}{|c|c|c|c|c|c|c|c|c|c|c|c|}
\hline tile & we & 10 & $\because 1$ & 30 & 411 & il & (ii) & 71 & או & !H & liøh \\
\hline & $\tilde{5} \cdot \underline{2}$ & 73 & $8 \pi$ & 9. & $I(x)$ & 10.7 & 111 & 117 & $1 \geq 3$ & 131 & $1+7$ \\
\hline & 7 & -7 & si & 9 & 97 & l & $1 \geq 0$ & 127 & 138 & 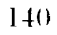 & \\
\hline 50 & is & 80 & 90 & $91 ;$ & 107 & Il & 117 & $12 \mathrm{~s}$ & 134 & $1+s$ & it \\
\hline English monoglot & $6 i 7$ & زן & 98 & 104 & 107 & 114 & 119 & lיר & 137 & $146 ;$ & 1711 \\
\hline
\end{tabular}

The total number of English-speaking monoglot students from the rural districts of Wales being small, t5 only. the frequency curre as well as the percentile curve representing the performance of this wroup is somewhat irregular, but the superiority of the curves of performance of this group over those of the Welsh bilingual students from similar districts is clearly seen, and it becomes still more emphatic when the curves are "smoothed.'

It will be readily granted that the language a child uses in his play and in his associations with youthful companions is charged with a high degree of affective value, and that this languagere occupies his conscionsness by preference throughout the period of childhood. Where the language of play is also that of the home and of the church, as is the case with Welsh-speaking children in the rural areas of Wales. the child's word symbols are formed in that language with a strong affective tone.

In the urban and industrial districts of Wales, bilingual children very generally adopt English as the language of play. Where Welsh is the language of the home and the church in such districts, it is found that the language used in play tends to invade the home and the church, 
and gradually to become that in which a child responds to his parents even when they address him in Welsh. The children also use English in their conversation with one another in the home in preference to Welsh. Under such circumstances any emotional conflict between the use of Welsh and English that may arise is resolved by the child at an early age, and English is used by him on every available occasion. In urban and industrial districts the child who first learnt Welsh at his home and subsequently learnt English from his play companions thus enjoys almost the same emotional freedom from language conflict as the monoglot in the same district, for play has some cathartic influence in its tendency to relieve the tension due to the dominance of the 'reality principle.' The child can thus enter upon his school duties and find little difficulty in adopting as his own the English word symbols there used. The English vocabulary of these children, however, does not carry as fully symbolic a significance as that of the English monoglot, as there has been some confusion and lack of definiteness in the meaning through the substitution of a word in the second language for that of the mother tongue, where the word was more fully charged with affect. The words 'home' and 'bread' cannot be expected to have the same fulness of affective tone to a Welsh-speaking child as the words 'cartref' and 'bara' that he first called these objects by. This possibly accounts for the difference found by Frank Smith in his investigation referred to in Section III $e$, and in the tests for dextrality, rhythm and composition made upon urban children and described in Section III $b, c$ and $e$ of this article.

The Welsh-speaking child in rural districts begins to use English symbols at school in reading and writing before he has learnt to express himself adequately in his mother tongue. Welsh is somewhat neglected or almost entirely ignored and English is learnt slowly and laboriously. Since the Welsh symbols that are ignored have for him a high affective tone, and since the cathartic influence of play does not operate, for he uses Welsh in his play, a conflict must arise between his self-regarding sentiment or positive self-feeling and his negative self-feeling or his instinct for submission. I suggest that this may account for the large difference found between bilinguists and monoglots in rural districts in this investigation as compared with the smaller difference between bilinguists and monoglots in urban and industrial districts. 


\section{CONCLUSiONs.}

1. Monoglot children in rural districts in Wales show a considerable superiority over bilingual children in the same districts when tested by the Binet scale of intelligence.

2. University students coming from rural areas in Wales show the same differentiation in a test of intelligence.

3. This difference appears to be of a permanent nature since it was seen to persist in students throughout their university careers.

4. In rural districts the sharpest rise in the curve for vocabulary tends to occur with monoglot children at $s$ or ! years of age. In the case of bilingual children this is postponed until 10 or 11 years of age.

5. The range of vocabulary of monoglot children is higher than that of bilinguists (either in Welsh or in English).

6. When writing English the Welsh bilingual child uses his memory to recall altemate word symbols in two languages instead of his reasoning power which should make the image clearer and more signiticant to him. He thus exercises himself with indefinite symbols during a period when his disposition is to be precise and definite.

7. The results of the tests for dextrality suggest that a confusion has been carried over from the brain area concerned with language to the related specialised area connected with the use of the right hand in gesture or in writing. The bilinguists were found to be much more confused in this respect than monoglots both in rural and in urban districts.

R. Children in urban districts tested by the Binet scale and university students from similar districts in Wales estimated for intelligence hy a group test show an inconsiderable difference between monoglots and bilinguists.

9. But mental confusion is seen to exist in bilingual children to a higher degree than in monoglot children even in urban areas by the tests for dextrality, and also in the rhythm tests when the organs of speech expression functioned in singring a series of rhythms to "lan,' the monoglots showing a consistent superiority orer the bilinguists at each year of age from $T$ to 1.2 : a difference that did not appear in the same rhythms when the children responded by tapping.

10. It is sugrested that the greatest influence on the mental confusion occurring in bilingualism is exerted by the language used by bilingual children in their play and in their free association with youthful companions when that language is not also that in which they are first taught at school.

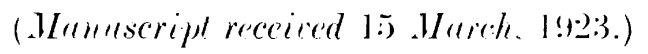

